\title{
Biota of the WAP complex - starting a citizen science project for West Africa's largest complex of protected areas
}

\author{
Received: 2016-11-14; accepted: 2016-11-19
}

\author{
Marco Schmidt ${ }^{1 *}$, Eméline Assédé2 ${ }^{2}$ Horst Oebel $^{3}$, Jakob Fahr ${ }^{4}$, Brice Sinsin ${ }^{2}$ \\ ${ }^{1}$ Senckenberg Biodiversity and Climate Research Centre (BiK-F), Data and Modelling Centre \& Senckenberg Research In- \\ stitute Frankfurt, Department of Botany and molecular Evolution, Senckenberganlage 25, 60325 Frankfurt am Main, Ger- \\ many. \\ ${ }^{2}$ Université d'Abomey-Calavi, Faculté des Sciences Agronomiques, Laboratoire d'Ecologie Appliquée, 01 BP 526, Coto- \\ nou, Benin. \\ ${ }^{3}$ Program Transboundary Biosphere Reserve WAP Region, Deutsche Gesellschaft für Internationale Zusammenarbeit (GIZ) \\ GmbH, 08 B.P. 1132 Tri Postal, Cotonou, Benin \\ ${ }^{4}$ Zoological Institute, TU Braunschweig, Braunschweig \& Department of Migration and Immuno-ecology, Max Planck In- \\ stitute for Ornithology (MPIO), Am Obstberg 1, 78315, Radolfzell, Germany. \\ * corresponding author. E-mail address: mschmidt@senckenberg.de
}

Summary: To improve data availability and exchange in the area of the WAP complex, West Africa's largest continuous area of reserves, we set up a citizen science project on the iNaturalist platform, allowing contribution of observations, ideally documented by photographs and/or sounds. Along with the project we created a number of online field guides for the local flora. Within only two months, 852 observations of 312 species have been assembled. We expect this dataset to further grow in the future and complement existing data sets from scientific collections and surveys.

Key words: WAP complex, citizen science, observation data, digital photos

\section{BIOTA OF THE WAP COMPLEX - DÉMARRAGE D'UN PROJET DE SCIENCE CITOYENNE POUR LE PLUS GRAND COMPLEXE D'AIRES PROTÉgÉES EN AFRIQUE DE L'OUEST}

Résumé: Afin d'améliorer la disponibilité et l'échange de données dans le domaine du complexe WAP, le plus grand complex d'aires protégées en Afrique de l'Ouest, nous avons mis en place un projet scientifique citoyen sur la plate-forme iNaturaliste. Parallèlement à ce projet, un certain nombre de guides de terrain ont été créé en ligne pour la flore locale. En deux mois déjà, 852 observations sur 312 espèces ont été rassemblées. Nous espérons pour l'avenir une croissance continue de cette base de données qui sera également complétée par celles existantes au niveau des collections et travaux scientifiques.

Mots clés: Complexe WAP, science citoyenne, données d'observation, photos numériques

\section{BIOTA OF THE WAP COMPLEX - START EINES BÜRGERWISSENSCHAFTSPROJEKTES FÜR DEN GRÖSSTEN KOMPLEX VON SCHUTZGEBIETEN IN WESTAFRIKA}

Zusammenfassung: Um Datenverfügbarkeit und -austausch in der Region des WAP-Komplexes, Westafrikas größtem zusammenhängenden Gebiet von Schutzgebieten, zu verbessern, haben wir ein Bürgerwissenschaftsprojekt auf der iNaturalistPlattform aufgesetzt, zu dem mit Fotos und/oder Klangaufnahmen dokumentierte Naturbeobachtungen hinzugefügt werden können. Projektbegleitend haben wir eine Reihe von Online-Feldführern für die lokale Flora zusammengestellt. Innerhalb von nur 2 Monaten wurden 852 Beobachtungen von 312 Arten beigetragen. Wir erwarten, dass diese Datensammlung in der Zukunft weiterwächst und existierende Daten aus naturwissenschaftlichen Sammlungen und Erhebungen ergänzt.

Schlagworte: WAP-Komplex, Bürgerwissenschaft, Beobachtungsdaten, Digitalfotos

\section{INTRODUCTION}

Biodiversity data for West Africa's savanna region is scarce. Together with the Sahara desert, the drylands surrounding it constitute one of the largest 'white spots' remaining on GBIF's global map of species occurrences (http://www.gbif.org/occurrence). This lack of publicly available data is detrimental to biodiversity science as well as to conservation actions in the region (STEPHENSON et al. 2016). As a new approach to improve the situation, we started a citizen science project collecting biodiversity observations within the area of the WAP complex (Fig. 1). Citizen science, presently experiencing increased attention, has a long tradition, and some citizen scientist datasets rank among the world's largest biodiversity datasets (e.g. eBird http://ebird.org with $>500$ Mio. records). This project, called 'Biota of the WAP complex' (www.inaturalist.org/projects/biota-of-the-wap-complex ) was initiated on iNaturalist, an international citizen science platform for sharing biodiversity observations, usually georeferenced photo records. 


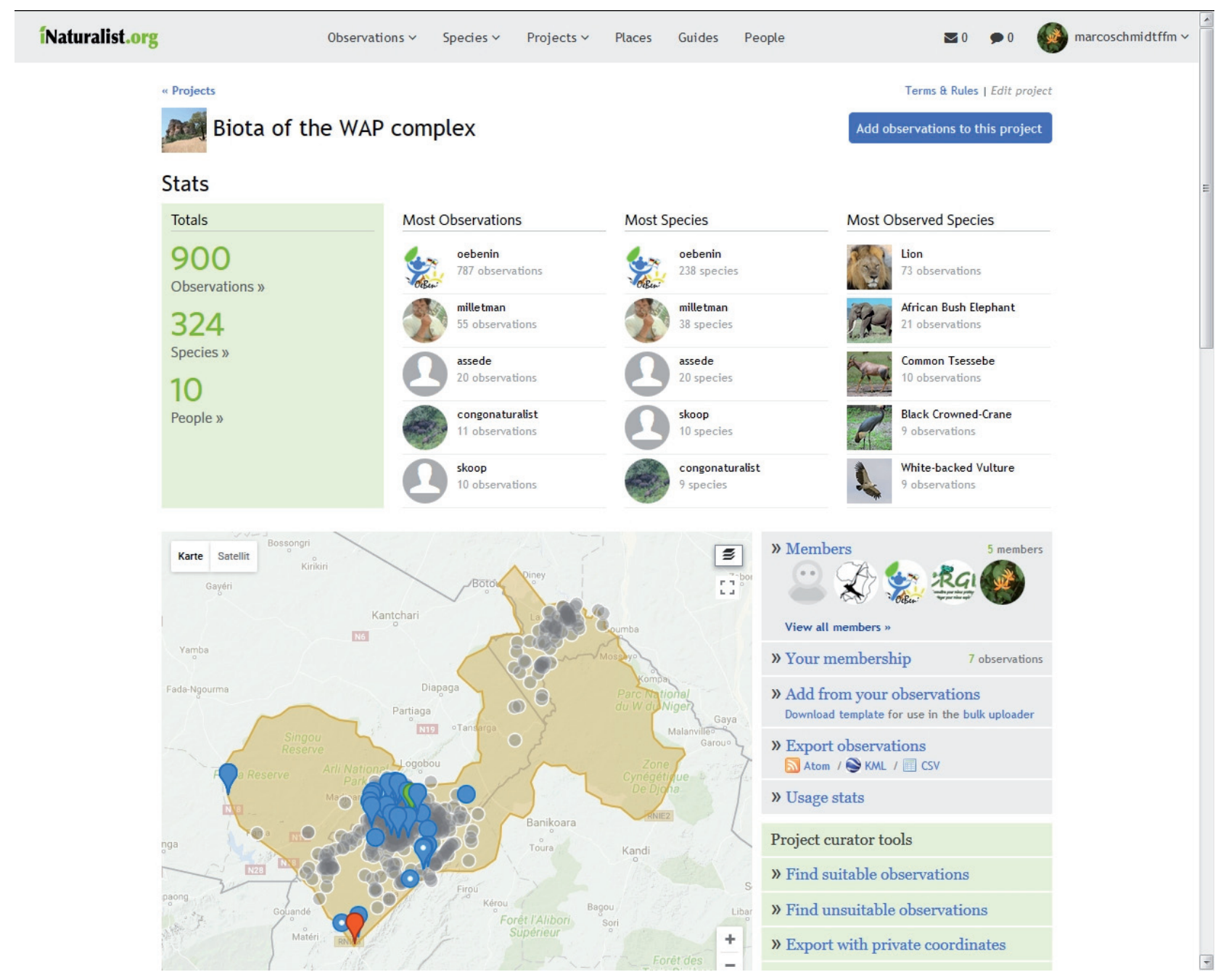

Fig. 1: Screenshot of the project's start screen, offering an overview of the number of observations, taxa and contributors as well as a map, search and export options. / Capture d'écran de la page d'acceuil du projet, montrant un aperçu du nombre d'observations de taxons et contributeurs, ainsi qu'une carte avec les options de recherche et d'exportation. / Screenshot der Startseite des Projekts mit der Zahl der Beobachtungen, Arten und Beitragenden, sowie einer Landkarte, Such- und Exportfunktionen.

The WAP complex is West Africa's largest continuous area of reserves, including the W Transborder Park (Benin, Burkina Faso, Niger), the National Parks of Arly (Burkina Faso) and Pendjari (Benin) as well as adjacent reserves and hunting concessions (for details on protection status, governance, etc. see KONRAD 2015).

\section{Methods}

Starting a project on iNaturalist is straightforward and simple, mainly defining the target taxa and regions as well as options for contributions. Existing data on the platform have been added to the project, hitherto undetermined photo records have been identified, and people have been invited to contribute. iNaturalist relies on standard lists for its taxonomy and nomenclature, e.g. The Plant List (www.theplantlist.org; РATON 2013) for plants and The Clements Checklist (CLEMENTs et al. 2016) for birds, in order to harmonize taxon names and data exchange with other data providers such as GBIF (www.gbif.org).

Along with the project, we also decided to create guides to the local flora (Fig. 2): while field guides exist for birds (BALANCA et al. 2007) and mammals (LAMARque 2004), a guide book to the plants of the WAP complex is still missing. So we compiled a species list from the checklists of MbaYngone et al. (2008), OuÉDraogo et al. (2011), NACOUlma (2012) and AssÉDÉ et al. (2012) and added in a half-automated process (provided by iNaturalist for producing such guides) open access descriptions and illustrations with suitable licences, which were available via Encyclopedia of Life (www.eol.org) or Wikipedia and were in many cases originally from the sites of the Zimbabwe Flora (Hyde et al. 2016) and African Plants - a photo guide (DrESSLER et al. 2014). Several taxa had to be curated or added to iNaturalist's taxonomic backbone in order to be integrated into the guides. Since the number of taxa for an iNaturalist guide is restricted, we created four separate guides for ferns (www.inaturalist.org/guides/3961), monocots (www.inaturalist.org/guides/3918), legumes (www.inaturalist.org/guides/3962) and other dicots (http://www.inaturalist.org/guides/3963).

\section{RESULTS}

The present GBIF occurrences for the area of the WAP complex (defined as a rectangle from $10.5^{\circ} \mathrm{N}-12.8^{\circ} \mathrm{N}$ and $0.4^{\circ} \mathrm{E}$ - 


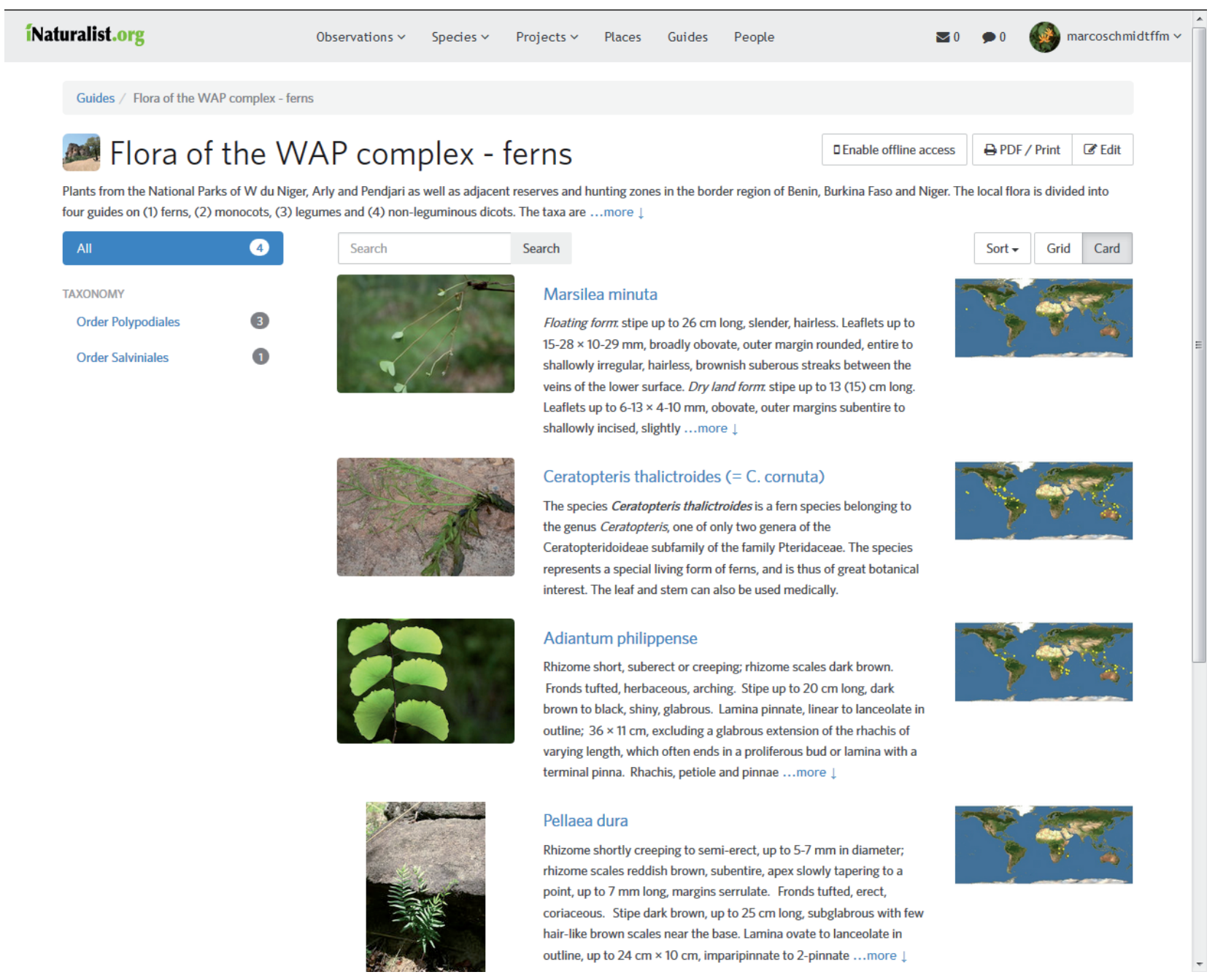

Fig. 2: Screenshot of the smallest of the four guides to the flora of the WAP complex showing a representative photo, descriptive text and maps of the global distribution of the species. / Capture d'écran de la plus petite des quatre guides de la flore du complexe WAP montrant des photos représentatives d'espèces, les textes descriptifs ainsi que les cartes de distribution de ces espèces. / Screenshot des kleinsten der vier Naturführer zur Flora des WAP-Komplexes mit repräsentativen Fotos, Beschreibungen und Karten zur globalen Verbreitung der jeweiligen Art.

$\left.3.5^{\circ} \mathrm{E}\right)$ comprise 50,575 records, largest contributors are the National Forest Census of Benin (12871), the West African Vegetation Database (9222, SCHMIDT et al. 2012) and collection records from Naturalis Biodiversity Center (2525), well representing the area due to the work on the Flore du Benin (Akoegninou et al. 2006). The majority of these records is from Benin (36343), followed by Burkina Faso (12017) and Niger (1169). Taxonomically, the largest share of observations is contributed by plants (36949) followed by animals (13545). Not a single record on fungi has been found for the area on GBIF.

Only two months after the start of the Biota of the WAP project, the data consist of 900 observations of 324 species contributed by 10 observers. Integration of data into GBIF takes place by harvesting the ABCD or Darwin Core archives of its contributors in regular intervals, and all research grade records (with at least two identical identifications at species level) will be contributed to GBIF through regular data harvests. This makes data easily available for both the research and conservation community.

\section{Discussion}

Up to now, most users of the WAP project are scientists rather than amateurs, the usual user group targeted by citizen science approaches. This may be partly due to the fact that internet access, although much improved in the past decade, is still limited and expensive for most people in West African. Platforms like iNaturalist and other citizen science approaches have not yet found the popularity they have in many countries in Europe, North America and Asia. Furthermore, larger citizen associations focusing on conservation and an interest in biodiversity - as existing in many countries in Europe, North America and also South Africa - are missing. Local NGOs/associations including OeBenin (Organisation pour la promotion de l'éducation des filles au Bénin) and ACTAG-PRW (Association des Campements Touristiques pour l'Appui à la Gestion du Parc Régional W) however have been actively contributing observations.

Even though the user community is still small, the basic principle of contributing photo observations and getting assistance in determination is working well and we see good future potential of using the 'Biota of the WAP complex' 
project for training local students in the biodiversity and conservation domain and for guides and visitors in ecotourism, providing at the same time a showcase of the protected areas and bringing domain experts and 'citizen scientists' closer together. Since digital cameras with GPS and camera traps have become affordable to the interested public, the number of photo observations is growing rapidly. Such photo observations are in most cases sufficiently documented and well organized by platforms like iNaturalist to allow verification by taxon experts (both scientists and laymen).

The relatively small citizen science community in West Africa further profits from the expertise of a large international platform, especially for taxa with a large group of citizen scientists (e.g. birdwatchers).

For botany, this new source of observation data can be expected to complement existing data sources such as collection data and vegetation plot data. It may close a gap in occurrence data since (1) botanical research activities in the Sudanian savannas are seasonally biased towards the end of the wet season when the majority of plants is identifiable (Schmidt 2006, Fig. 9D) and (2) vegetation plot data often miss rare species (SCHMIDT et al. 2010) due to small areas of investigation. Photographers are expected to be more active in the dry season (when the chances to see large mammals in the reserves are high), conspicuous species and species rarely encountered will be better represented than in plot data.

For all taxa, the amount and coverage of data is increased and with sufficient participation may become an important contribution to species monitoring.

\section{ACKNOWLedgements}

We thank all photographers contributing observations to the project and to the guides, especially OeBenin (www.facebook.com/ OeBenin), a Benin NGO working on education and nature conservation and the association ACTAG-PRW (www.asso-parcw.com). MS is presently financed by the GFBio project (DFG grant HI $1538 / 2-2$ ). Some observations were done with financial support by a Rufford small grant to EA.

\section{REFERENCES}

AKoÈgninou A, van der Burg WJ, van der MaEsen LJG, Adjakidjè V, EsSOU JP, Sinsin B \& Yédomonhan (2006): Flore Analytique du Bénin. Backhuys Publishers, Cotonou \& Wageningen, $1034 \mathrm{p}$.

Assédé EPS, Adomou AC \& Sinsin B (2012): Magnoliophyta, Biosphere Reserve of Pendjari, Atacora Province, Benin. Check List 8(4): 642-661

BALANÇA G, CORNÉLIS D \& Wilson R (2007): Les oiseaux du complexe WAP / Birds of the WAP complex. ECOPAS, Ougadougou, $199 \mathrm{p}$.
Clements JF, Schulenburg TS, Iliff J, Roberson D, FreDERICKS TA, Sullivan BL \& WoOd CL (2016): The eBird: Clements checklist of birds of the world: v2016. http:// www.birds.cornell.edu/clementschecklist/download/

DressLer S, SCHMIDT M \& ZiZKa G (2014): Introducing African Plants - A Photoguide - an interactive identification tool to continental Africa. Taxon 63: 1159-1161

Hyde MA, Wursten BT, Ballings P \& Coates Palgrave M (2016): Flora of Zimbabwe: Home page. http://www. zimbabweflora.co.zw/ visited 2016-11-08

KonRad T (2015): Governance of Protected Areas in West Africa - The case of the W-Arly-Pendjari (WAP) Complex in Benin and Burkina Faso. PhD thesis, Julius-Maximilian Universität Würzburg, 274 p.

LAMARQUE F (2004): Les grand mammifères du complexe WAP / Large mammals of the WAP complex. ECOPAS, Ouagadougou, $268 \mathrm{p}$.

Mbayngone E, Schmidt M, Hahn-Hadjali K, Thiomiano A \& Guinko S (2008): Magnoliophyta of the partial faunal reserve of Pama, Burkina Faso. Check List 4(3): 251-266

Nacoulma BMI (2012) Dynamique et strategies de conservation de la vegetation et de la phytodiversité du complexe écologique du Parc National du W du Burkina Faso. PhD thesis, Université de Ougadougou, 202 p.

Oú́draogo O, Schmidt M, Thiombiano A, Hahn K, Hien M, Guinko S \& ZizKa G (2011): Magnoliophyta, Aryl National Park, Tapoa, Burkina Faso. Check List 7(1): 85-100

Paton AJ (2013): From Working List to Online Flora of All Known Plants - Looking Forward with Hind-sight. Missouri Bot Gard Bull 99: 206-213

Schmidt M (2006): Pflanzenvielfalt in Burkina Faso - Analyse, Modellierung und Dokumentation. PhD thesis, Goethe Universität Frankfurt am Main

Schmidt M, Janssen T, Dressler S, Hahn K, Hien M, Konaté S, Lykke AM, Mahamane A, Sambou B, Sinsin B, Thiombiano A, Wittig R \& Zizka G (2012): The West African Vegetation Database. Biodivers Ecol 4: 105-110

Schmidt M, Thiombiano A, Dressler S, Hahn-Hadjali K, Guinko S \& Zizka G (2010): Phytodiversity Data strengths and weakness: A comparison of collection and releve data from Burkina Faso. In VAN DER BURGT XM, vAN Der Maesen LJG, Onana JM (eds) Systematics and Conservation of African Plants. Royal Botanic Garden, KEW: 829-837

Stephenson PJ, Bowles-Newark N, Regan E, StanwellSmith D, Diagana M, Höft R, Abarchi H, Abrahamse T, Akello C, Allison H, Banki O, Batieno B, Dieme S, Domingos A, Galt R, Githaiga CW, Guindo AB, HafaShimana DLN, Hirsch T, Hobern D, KaAya J, KagGwa R, Mphatso Kalemba M, Linjouom I, Manaka B, Mbwambo Z, Musasa M, Okoree E, Rwetsiba A, Siam AB, ThiomBIANO A (2016): Unblocking the flow of biodiversity data for decisionmaking in Africa. Biol Conserv. DOI: 10.1016/j. biocon.2016.09.003 